Tạp chí Khoa học và Công nghệ biển T10 (2010). Số 2. Tr 77 - 90

\title{
ẢNH HƯỞNG CỦA THỨC ĂN ĐẾN SINH TRƯỞNG, TỶ LÊ SỐNG VÀ CHUYỂN HÓA PROTEIN CỦA CÁ TRĂM ĐEN MYLOPHARYNGODON PICEUS (RICHARDSON, 1846)
}

\author{
TẠ THỊ BÌNH
}

Trường Đại học Vinh

\author{
NGUYẼ̃N VĂN TIÊN
}

Viện Nghiên cứu nuôi trồng thủy sản I

\begin{abstract}
Tóm tắt: Nghiên cưu này được thục hiện để tìm ra loại thức ăn thích hợp cho cá trắm đen (Melopharyngodon piceus) giai đoạn 30 - 100 g. Sủ dụng 3 loại thức ăn khác nhau BLC1, BLC2, BLC3. Cá thí nghiệm được thả trong 6 ô ao với diện tích $350 \mathrm{~m}^{2} / \hat{o}$, mật độ thả 1 $\mathrm{con} / \mathrm{m}^{2}$. Cho cá ăn ngày 2 lần các loại thức ăn trên ở múc gần thỏa mãn, vớc tính tù $3-5 \%$ khối lượng cá/ngày. Kiểm tra tốc độ tăng trương của cá 20 ngày/làn, mỗi lần cân 50 cá thể/ô. Tỷ lệ sống, hệ số thức ăn và phần trăm chuyển hóa protein được xác định vào thời điểm kết thúc thí nghiệm. Kết quả cho thấy, sau 60 ngày nuôi cá trắm đen tăng truởng nhanh nhất ở nghiệm thức BLC2 (ADG 0,11 cm/con/ngày và $1,14 \mathrm{~g} /$ con/ngày; SGR 0,69\%/ngày và 2,17\%/ngày), sau đó là ở nghiệm thức BLC1 (ADG 0,1 g/con/ngày và 0,92g/con/ngày; SGR $0,59 \%$ và $1,93 \% / n g a ̀ y)$ và chậm nhất ở nghiệm thức BLC3 (ADG 0,085cm/con/ngày và 0,74g/con/ngày; SGR 0,58\% và 1,72\%/ngày). Khối luợng trung bình của cá khi kết thúc thí nghiệm lần lươt là 93,61 $\mathrm{g} / \mathrm{con}, 86,96 \mathrm{~g} / \mathrm{con}$ và $68,9 \mathrm{~g} / \mathrm{con}$ ở các công thức BLC2, BLC1 và BLC3. Tỉ lệ sống của cá thí nghiệm đạt trên 99\%, hệ số thức ăn lần luợt của các loại thức ăn là $B L C 1(2,1), B L C 2(1,9)$ và $B L C 3(2,4)$. Phần trăm chuyển hóa protein của các loại thức ăn là BLC1 (19,59), BLC2 $(19,90)$ và BLC3 $(16,89)$.Tuy nhiên, theo kết quả phân tích ANOVA cho thấy các chỉ tiêu (khối lượng trung bình, $A D G$ về khối lượng FCR và PPD) sai khác có ý nghĩa $(P<0,05)$, còn lại các chỉ tiêu khác sai khác không có ý nghĩa $(P>0,05)$.
\end{abstract}

\section{MỞ ĐÀ̀U}

Cá trắm đen (Mylopharyngodon piceus) thuộc họ Cyprinidae (bộ Cypriniformes) là loài cá ăn động vật thân mềm (Nguyễn Văn Hảo và Ngô Sỹ Vân, 2001). Cá Trắm đen là loài cá đặc trưng phân bố từ sông Amua (Liên Xô) đến miền Nam Trung Quốc và phía Bắc Việt Nam (Nico và ctv, 2005). Đối với nghề nuôi, cá trắm đen là đối tượng cá nước ngọt nuôi có triển vọng, do sinh trưởng nhanh, sản lượng cao, thịt thơm ngon. Mặt khác chúng có khả năng nuôi rộng rãi ở các thủy vực nước ngọt. Ở Trung Quốc cá trắm đen là 1 
trong 4 loài cá truyền thống được nuôi phổ biến, sản lượng hàng năm đạt khoảng 170.000 tấn (Leng Xiang-Jun, Wang Zun, 2003). Năm 2003, Leng Xiang-Jun và Wang Zun đã nghiên cứu về nhu cầu dinh dưỡng của cá trắm đen, lập công thức thức ăn, chế biến thức ăn viên bằng nguyên liệu địa phương. Nghiên cứu này đã mở ra triển vọng về phát triển sản xuất thức ăn công nghiệp nuôi cá trắm đen ở Trung quốc .

Ở Việt Nam nghề nuôi cá trắm đen đã phát triển trong khoảng 2 năm trở lại đây ở các tỉnh Hải Dương, Bắc Ninh, Ninh Bình, Hưng Yên, Vĩnh Phúc (Nguyễn Thị Diệu Phương và ctv, 2009). Tuy nhiên, chỉ đang dừng lại ở hình thức nuôi ghép với tỷ lệ rất nhỏ trong các hệ thống ao hồ, đầm với cá Trắm cỏ, Trôi, Mè trắng, Mè hoa chủ yếu để tận dụng nguồn thức ăn tự nhiên trong ao. Sản lượng chưa đáp ứng được nhu cầu của người tiêu dùng. Một trong các khâu có thể nâng cao được sản lượng là phải có hình thức nuôi phù hợp, trong đó thức ăn dùng để nuôi đóng vai trò quan trọng. Hiện tại thức ăn dùng để nuôi chủ yếu là động vật thân mềm (ốc, hến,...), loại thức ăn này hiện nay ngày càng ít và đây là hạn chế để phát triển nghề nuôi cá trắm đen. Trước thực tế đó việc tìm ra loại thức ăn phù hợp cho nuôi cá trắm đen trong điều kiện Việt Nam là cần thiết.

\section{VẬT LIỆU VÀ PHƯƠNG PHÁP NGHIÊN CÚU}

\section{Thời gian và địa điểm thực hiện}

Thí nghiệm nuôi cá trắm đen trong ao được tiến hành tại Viện Nghiên cứu nuôi trồng thủy sản I (NCNTTS) ở Đình Bảng, Từ Sơn, tỉnh Bắc Ninh từ tháng 6 đến tháng 9 năm 2009.

\section{Vật liệu - cá thí nghiệm}

Cá trắm đen được mua từ Mê Linh, tỉnh Vĩnh Phúc. Trước khi bố trí thí nghiệm cá được luyện cho ăn thức ăn Cargill 7424 có hàm lượng protein tối thiểu 40\%, lipid tối thiểu là $8 \%$ kích thước $1,2 \mathrm{~mm}$. Sau đó cho cá ăn thức ăn mới. Cỡ cá thí nghiệm: 24,5$26,4 \mathrm{~g} / \mathrm{con}$.

\section{Thức ăn thí nghiệm}

Thức ăn sử dụng trong thí nghiệm gồm 3 loại do Viện NCNTTS I sản xuất là: BLC1(100\% bột cá), BLC2 (thay thế 25\% bột cá bằng men bia), BLC3 (thay thế 50\% bột cá bằng men bia). Thành phần dinh dưỡng các loại thức ăn thí nghiệm thể hiện ở bảng 1 . 
Bảng 1: Thành phần nguyên liệu và dinh dưỡng của công thức thức ăn sử dụng nuôi cá trắm đen thí nghiệm $(\%)$

\begin{tabular}{|c|c|c|c|}
\hline \multirow{2}{*}{ Nguyên liệu } & \multicolumn{3}{|c|}{ Công thức thức ăn } \\
\hline & BLC1 & BLC2 & BLC3 \\
\hline Gluten ngô 55\% CP & 5 & 5 & 5 \\
\hline Men bia khô & 0 & 12 & 24 \\
\hline Bột cá CP/CL 60\%/8\% & 40 & 30 & 20 \\
\hline Khô dầu đỗ $44 \%$ CP & 21 & 21 & 20 \\
\hline Dầu cá & 3 & 3 & 3.7 \\
\hline Cám mỳ & 16 & 13.51 & 12.65 \\
\hline Bột mỳ trắng & 14 & 14 & 13 \\
\hline Choline chloride & 0.1 & 0.1 & 0.1 \\
\hline Vitamin C (coated) & 0.04 & 0.04 & 0.04 \\
\hline Chất chống oxy hóa (ethoxiquin) & 0.02 & 0.02 & 0.02 \\
\hline Vitamin/mineral premix $\left({ }^{1}\right)$ & 0.75 & 0.75 & 0.75 \\
\hline DL-methionine & 0.1 & 0.18 & 0.25 \\
\hline L-lysine $\mathrm{HCl}$ & 0 & 0.4 & 0.5 \\
\hline Protein thô & 41.78 & 41.63 & 41.76 \\
\hline Lipid thô & 7.46 & 7.34 & 7.14 \\
\hline Xơ thô & 3.0 & 2.8 & 2.7 \\
\hline Độ ẩm & 6.56 & 5.22 & 9.84 \\
\hline Năng lượng (KJ/kg) & 12.9 & 12.9 & 13.4 \\
\hline
\end{tabular}

(') Thành phần vitamin, khoáng bổ sung cho 1 kg thức ăn: Vitamin A $9000 \mathrm{IU}$, Vitamin D3 $1500 \mathrm{IU}$, Vitamin E: $60 \mathrm{mg}$, Vitamin K3: 4,5 mg, Vitamin C: $45 \mathrm{mg}$, Biotin: 0,15 mg, Folic acid: $3 \mathrm{mg}$, Niacin: $60 \mathrm{mg}$; Pantothenic acid: 22,5 mg, Thiamine B1: 13,5 mg, Đồng $\left(\mathrm{CuSO}_{4} .5 \mathrm{H}_{2} \mathrm{O}\right): 4,5 \mathrm{mg}$, Sắt $\left(\mathrm{FeSO}_{4} .7 \mathrm{H}_{2} \mathrm{O}\right): 75 \mathrm{mg}$, Mangan $\left(\mathrm{MnSO}_{4} \cdot \mathrm{H}_{2} \mathrm{O}\right): 30 \mathrm{mg}$, Kẽm

$$
\left(\mathrm{ZnSO}_{4} \cdot \mathrm{H}_{2} \mathrm{O}\right): 45 \mathrm{mg}
$$

\section{Phương pháp nghiên cứu}

Thí nghiệm được thực hiện trong 6 ô ao diện tích $350 \mathrm{~m}^{2} / \mathrm{o}$. Mật độ thả như nhau ở tất cả các ô $\left(1 \mathrm{con} / \mathrm{m}^{2}\right)$. Mỗi ô thí nghiệm thả 350 con cá. Thí nghiệm bố trí theo sơ đồ 
khối ngẫu nhiên. Mỗi nghiệm thức thức ăn lặp lại 2 lần. Cá cho ăn thức ăn thí nghiệm ở mức gần thỏa mãn, ước tính từ $3-5 \%$ khối lượng cá trong ao, ngày 2 lần. Định kỳ 20 ngày kiểm tra sức tăng trưởng của cá. Số mẫu cá là 50 cá thể/ô/1 lần thu mẫu. Thí nghiệm tiến hành trong 60 ngày.

Các yếu tố môi trường như nhiệt độ được theo dõi hàng ngày bằng nhiệt kế thủy ngân; $\mathrm{pH}, \mathrm{DO}$ được kiểm tra 1 ngày/lần bằng Test so màu; hàm lượng $\mathrm{NH}_{3}, \mathrm{NH}_{4}, \mathrm{NO}_{2}$, $\mathrm{NO}_{3}$ và $\mathrm{PO}_{4}$ được đo 1 lần/tuần bằng Test so màu (Germany).

Thành phần protein của cá trắm đen và thức ăn thí nghiệm được phân tích lúc bắt đầu và kết thúc thí nghiệm tại phòng sinh học thuộc Viện NCNTTS I. Phần trăm chuyển hóa protein được tính theo công thức:

$\mathrm{D}(\%)=$ Protein tăng lên (Protein gain)/ Protein ăn vào (Protein intake) x 100

Số liệu thí nghiệm được xử lý bằng phần mềm EXCEL. Ảnh hưởng của các loại thức ăn đến sinh trưởng của cá được xác định trên cơ sở phân tích phương sai 1 nhân tố. Tiêu chuẩn LSD để so sánh sự khác nhau giữa các nghiệm thức thức ăn.

\section{KẾT QUẢ VÀ THẢO LUẬN}

\section{Môi trường}

Trong quá trình thí nghiệm các yếu tố môi trường như $\mathrm{pH}$, hàm lượng ôxy hòa tan (DO), $\mathrm{PO}_{4}{ }^{3-}, \mathrm{NO}_{3}{ }^{-}, \mathrm{NO}_{2}{ }^{-}, \mathrm{NH}_{3}$ và $\mathrm{NH}_{4}{ }^{+}$dều nằm trong phạm vi thuận lợi cho sự sinh trưởng của cá trắm đen. Theo Nico và ctv (2005), nhiệt độ thích hợp cho cá trắm đen sinh truởng là $20-30^{\circ} \mathrm{C}$. Vì vậy, nhiệt độ trong quá trình thí nghiệm dao động từ khoảng 29,1 $36,6^{\circ} \mathrm{C}$ trung bình $32,7^{0} \mathrm{C}$ là hơi cao so với ngưỡng nhiệt độ thích hợp cho cá trắm đen sinh trưởng (bảng 2), tuy nhiên vẫn nằm trong khoảng chịu đựng của cá trắm đen.

Bảng 2: Một số yếu tố môi trường trong nước tại ao thí nghiệm

\begin{tabular}{|c|c|c|c|c|c|c|c|}
\hline $\begin{array}{c}\text { Nhiệt độ } \\
\left({ }^{\mathbf{0}} \mathbf{C}\right)\end{array}$ & $\mathbf{p H}$ & $\begin{array}{c}\mathbf{D O} \\
(\mathbf{m g} / \mathbf{l})\end{array}$ & $\begin{array}{c}\mathbf{P O}_{\mathbf{4}}{ }^{\mathbf{3}} \\
(\mathbf{m g} / \mathbf{l})\end{array}$ & $\begin{array}{c}\mathbf{N O}_{\mathbf{2}}^{-} \\
(\mathbf{m g} / \mathbf{l})\end{array}$ & $\begin{array}{c}\mathbf{N O}_{\mathbf{3}}^{-} \\
(\mathbf{m g} / \mathbf{l})\end{array}$ & $\begin{array}{c}\mathbf{N H}_{\mathbf{3}} \\
(\mathbf{m g} / \mathbf{l})\end{array}$ & $\begin{array}{c}\mathbf{N H}_{4} \\
(\mathbf{m g} / \mathbf{l})\end{array}$ \\
\hline 32,7 & & 4,9 & 0,26 & 0,09 & 1,83 & 0,03 & 0,36 \\
\hline $29,1-36,6$ & $7,3-8,6$ & $3,6-6,0$ & $0,1-0,5$ & $0,07-0,1$ & $1-2,3$ & $0,048-0,006$ & $0,25-0,63$ \\
\hline
\end{tabular}




\section{Tốc độ tăng trưởng}

1) - Tốc độ tăng trưởng về chiều dài và khối luợng ở giũa các công thức thí nghiệm: Tốc độ tăng trưởng tuyệt đối về chiều dài khi kết thúc thí nghiệm cao nhất là thức ăn BLC2 ( $0,11 /$ con/ngày), sau đó là BLC1 $(0,10 \mathrm{~cm} / \mathrm{con} /$ ngày), BLC3 $(0,08 \mathrm{~cm} / \mathrm{con} / \mathrm{ngày})$. Tốc độ tăng trưởng tương đối là $\mathrm{BLC} 1(0,59 \% /$ ngày), BLC2 $(0,69 \% /$ ngày $)$ và BLC3 $(0,58 \% /$ ngày) (bảng 3$)$. Như vậy tốc độ tăng trưởng tuyệt đối, tương đối về chiều dài của cá trắm đen nuôi sử dụng ba loại thức ăn $\mathrm{BLC} 1, \mathrm{BLC} 2, \mathrm{BLC} 3$ tương đương nhau $(\mathrm{P}>0,05)$.

Bảng 3: Sinh trưởng của cá trắm đen giữa các công thức thí nghiệm

\begin{tabular}{|c|c|c|c|c|c|c|}
\hline \multirow{2}{*}{ Chỉ tiêu } & \multicolumn{2}{|c|}{ BLC1 } & \multicolumn{2}{c|}{ BLC2 } & \multicolumn{2}{c|}{ BLC3 } \\
\cline { 2 - 7 } & $\mathbf{W}(\mathbf{g} / \mathbf{c o n})$ & $\mathbf{L}(\mathbf{c m} / \mathbf{c o n})$ & $\mathbf{W}(\mathbf{g} / \mathbf{c o n})$ & $\mathbf{L}(\mathbf{c m} / \mathbf{c o n})$ & $\mathbf{W}(\mathbf{g} / \mathbf{c o n})$ & $\mathbf{L}(\mathbf{c m} / \mathbf{c o n})$ \\
\hline Cá thả & $25,6 \pm 0,07^{\mathrm{a}}$ & $13.4 \pm 1,47^{\mathrm{a}}$ & $25,5 \pm 0,28^{\mathrm{a}}$ & $13 \pm 1,01^{\mathrm{a}}$ & $24,5 \pm 0,42^{\mathrm{a}}$ & $13 \pm 0,85^{\mathrm{a}}$ \\
\hline Cá thu & $81,2 \pm 26,8^{\mathrm{a}}$ & $18,97 \pm 1,76^{\mathrm{a}}$ & $93,61 \pm 22,8^{\mathrm{b}}$ & $19,17 \pm 2,41^{\mathrm{a}}$ & $68,9 \pm 14,6^{\mathrm{a}}$ & $18,28 \pm 1,36^{\mathrm{a}}$ \\
\hline $\begin{array}{c}\text { Tăng } \\
\text { thêm }\end{array}$ & 55,65 & 5,57 & 55,65 & 6,17 & 44,40 & 5,28 \\
\hline ADG & $0,93 \pm 0,13^{\mathrm{a}}$ & $0,1 \pm 0,007^{\mathrm{a}}$ & $1,14 \pm 0,08^{\mathrm{b}}$ & $0,11 \pm 0,028^{\mathrm{a}}$ & $0,74 \pm 0,01^{\mathrm{a}}$ & $0,085 \pm 0,007^{\mathrm{a}}$ \\
\hline SGR & $1,93 \pm 0,18^{\mathrm{a}}$ & $0,59 \pm 0,05^{\mathrm{a}}$ & $2,17 \pm 0,07^{\mathrm{a}}$ & $0,69 \pm 0,16^{\mathrm{a}}$ & $1,72 \pm 0,02^{\mathrm{b}}$ & $0,58 \pm 0,01^{\mathrm{a}}$ \\
\hline
\end{tabular}

Tại thời điểm kết thúc thí nghiệm tốc độ tăng trưởng khối lượng tuyệt đối theo ngày cao nhất là thức ăn BLC2 $(1,14 \mathrm{~g} / \mathrm{con} /$ ngày $)$ và có sự khác biệt thống kê $(\mathrm{P}<0.05)$ với hai nghiệm thức $\operatorname{BLC} 1(0,92 \mathrm{~g} / \mathrm{con} /$ ngày) và $\mathrm{BLC} 3(0,77 \mathrm{~g} / \mathrm{con} /$ ngày) (bảng 4$)$. Kết quả phân tích thống kê về tăng trưởng khối lượng tương đối của cá trắm đen qua 60 ngày nuôi cho thấy có sự khác biệt thống kê $(\mathrm{P}<0.05)$ giữa các nghiệm thức $\mathrm{BLC} 3(1,72 \% /$ ngày) với hai nghiệm thức BLC2 (2,17\%/ngày) và (BLC1 (1,93\%/ngày).

- Chiều dài và khối luợng của cá trắm đen trong quá trình thí nghiệm: Cá trắm đen khi bắt đầu bố trí thí nghiệm có chiều dài từ $13-13,4 \mathrm{~cm}$, sau 60 ngày thí nghiệm giá trị này đạt cao nhất ở nghiệm thức BLC2 $(19,17 \mathrm{~cm})$, kế tiếp là $\operatorname{BLC} 1(18,97 \mathrm{~cm})$ và $\mathrm{BLC} 3$ $(18,28 \mathrm{~cm})$. Khối lượng trung bình của cá trắm đen khi bố trí thí nghiệm từ 24,5 - 25,6 $\mathrm{g}$. Khối lượng trung bình khi kết thúc thí nghiệm là 93,61 g/con (BLC2), 81,2 g/con (BLC1) và $68,9 \mathrm{~g} / \mathrm{con}$ (BLC3). Qua hình 1 cũng cho thấy chiều dài và khối lượng trung bình của cá trắm đen khi sử dụng thức ăn BLC2 luôn cao nhất ở các lần kiểm tra sau đó đến thức ăn BLC1 và thấp nhất là thức ăn BLC3. Kết quả thí nghiệm này cho thấy cá trắm đen ở giai đoạn này sinh trưởng nhanh về khối lượng hơn chiều dài cơ thể. 

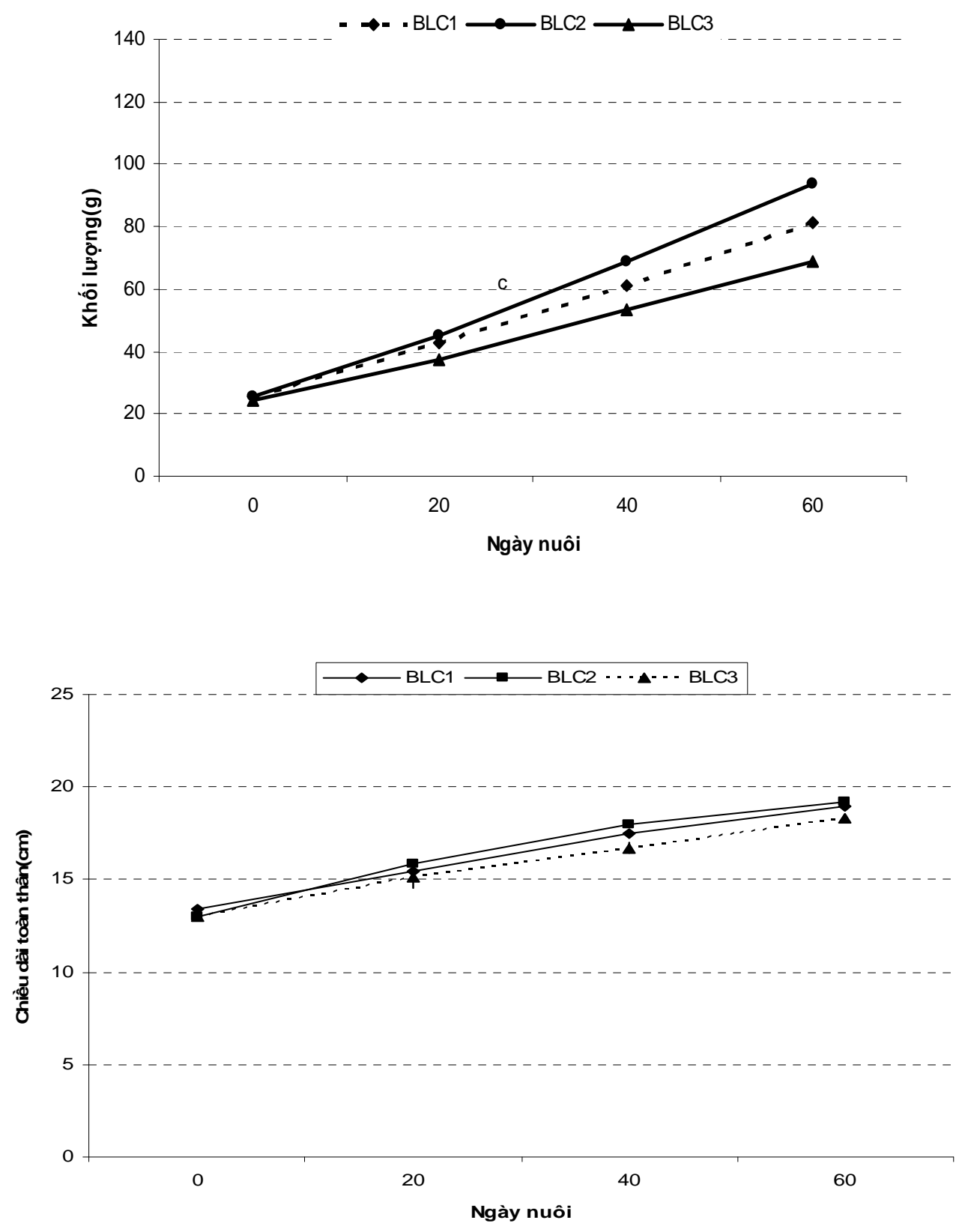

Hình 1: Trung bình chiều dài và khối lượng của cá trắm đen trong quá trình thí nghiệm tăng trưởng về khối lượng

- Tốc độ tăng trương tuyệt đối và tuoong đối về chiều dài: Tốc độ tăng trưởng tuyệt đối về chiều dài cá trắm đen tăng đều đặn trong giai đoạn ngày nuôi 0 - 20. Từ ngày 20 , 
tốc độ tăng trưởng tuyệt đối về chiều dài ở các nghiệm thức có xu hướng giảm. Và nghiệm thức BLC2 đạt tăng trưởng tuyệt đối cao nhất so với hai nghiệm thức còn lại ở các lần kiểm tra đầu nhưng lại đạt thấp nhất ở lần kiểm tra cuối cùng.

Tốc độ tăng trưởng tương đối về chiều dài của cá trắm đen tăng mạnh từ ngày 0 - 20 (BLC1: $0,75 \%$; BLC2: 8,35\%; BLC3 là 8,1\%), sau đó giảm dần đến ngày nuôi 60 (BLC1: $0,4 \%$; BLC2: $0,3 \%$; BLC3 là $0,45 \%)$.
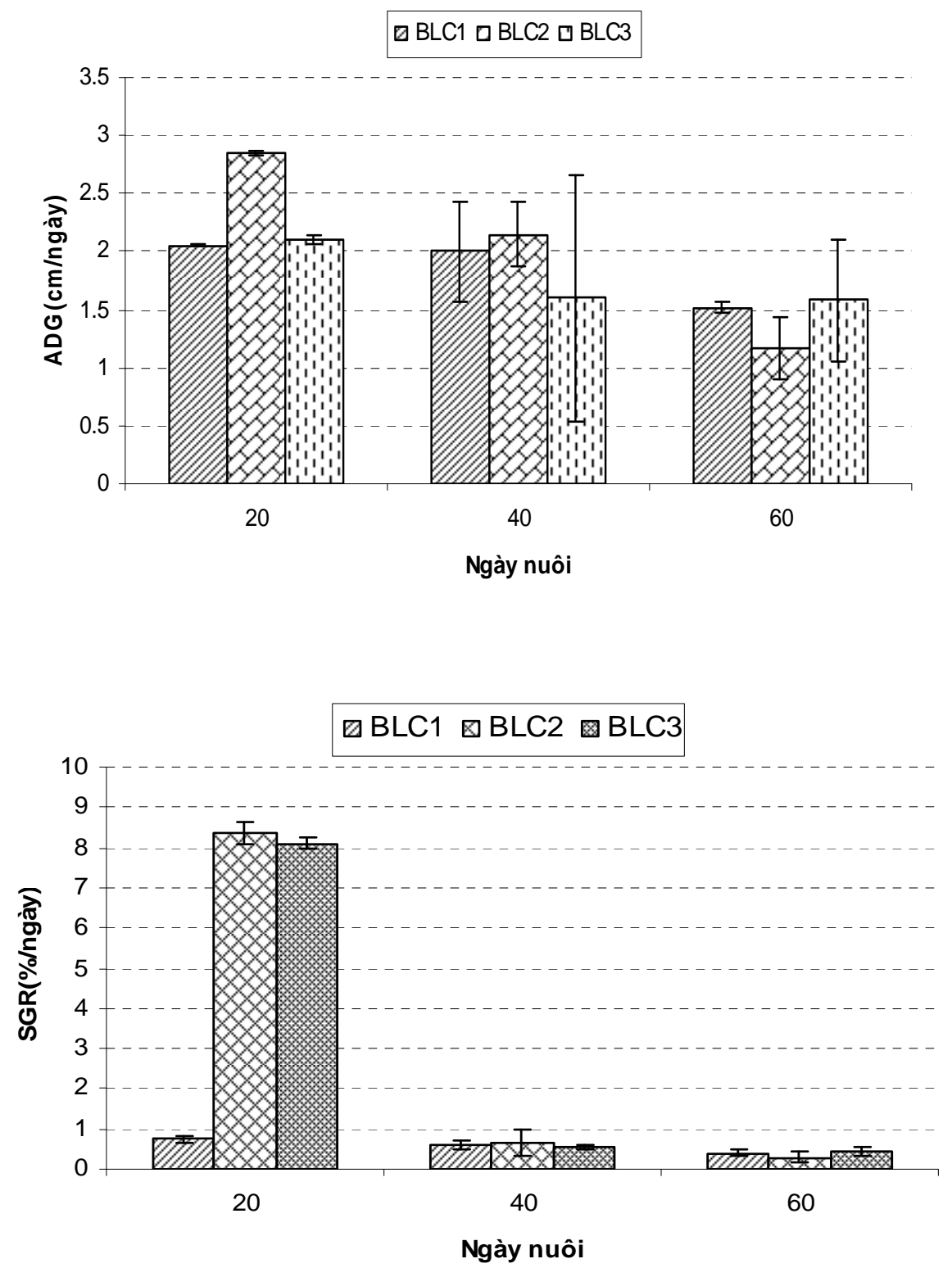

Hình 2: Tốc độ tăng trưởng tuyệt đối và tương đối về chiều dài 

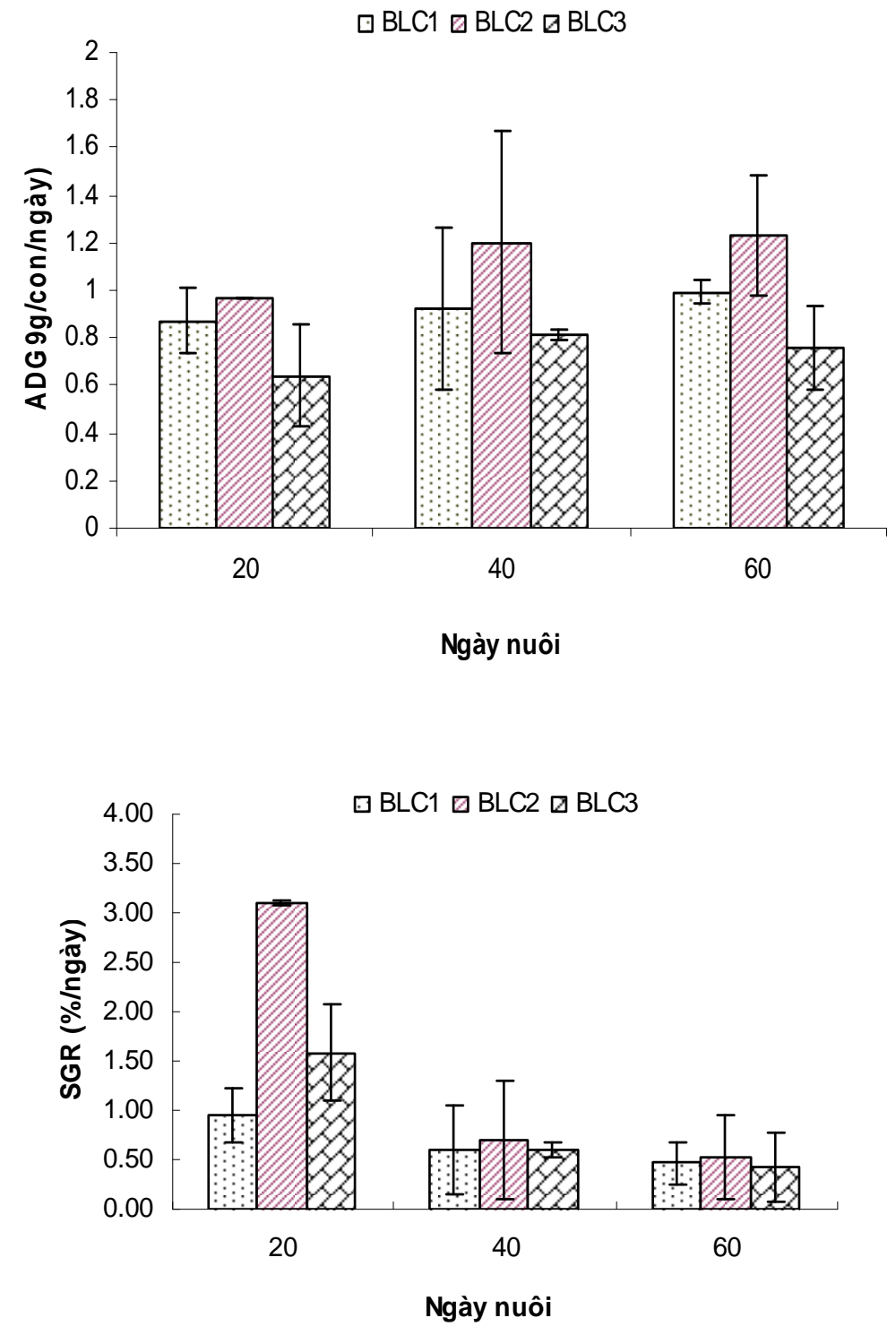

Hình 3: Tốc độ tăng trưởng tuyệt đối và tương đối về khối lượng

- Tốc độ tăng truơong tuyệt đối và tuơng đối về khối luợng: Tốc độ tăng trưởng tuyệt đối ngày của cá trắm đen ở nghiệm thức BLC1 và $\mathrm{BLB} 2$ tăng dần và đạt cao nhất ở ngày thứ 60 là $0,92 \mathrm{~g} / \mathrm{con} / \mathrm{ngày} \mathrm{và} 1,14 \mathrm{~g} / \mathrm{con} /$ ngày. Ngược lại, nghiệm thức BLC3 đạt mức cao nhất ở ngày thứ 40 là $0,82 \mathrm{~g} / \mathrm{con} / \mathrm{ngày}$.

Ở tất cả các nghiệm thức tốc độ sinh trưởng tương đối của cá trắm đen chỉ tăng từ ngày 0 - 20 (BLC1: 0,95\%; BLC2: 3,1\%; BLC3 là 1,58\%), sau đó giảm dần đến cuối chu kỳ nuôi (BLC1: 0,47\%; BLC2: 0,52\%; BLC3 là 0,42\%). 
Dựa trên kết quả phân tích ANOVA một nhân tố và dùng ngưỡng LSD để so sánh, kết quả cho thấy tốc độ tăng trưởng của cá trắm đen có sự khác nhau giữa các nghiệm thức, nghiệm thức BLC2 có tốc độ tăng trưởng cao nhất. Thức ăn ở cả 3 nghiệm thức có hàm lượng protein và lipid và thành phần acid amin là tương đương nhau (40\% protein, $7 \%$ lipid) nhưng khác biệt về tỷ lệ phối trộn nguyên liệu. Kết quả nuôi thử nghiệm cho thấy nguyên liệu thức ăn có ảnh hưởng rõ rệt đến hiệu quả sử dụng thức ăn và tốc độ tăng trưởng của cá.

Kết quả thí nghiệm cho thấy khi cá sử dụng thức ăn BLC2 (thay thế $25 \%$ bột cá bằng men bia) có tốc độ tăng trưởng của cá trắm đen cao hơn so với thức ăn BLC1 (100\% bột cá) và $\mathrm{BLC} 3$ (thay thế $50 \%$ bột cá bằng men bia). Điều này được giải thích có thể là do khi cá sử dụng thức ăn BLC2 (thay thế $25 \%$ bột cá bằng men bia) khả năng tiêu hóa của cá trắm đen tốt hơn so với hai công thức còn lại.

\section{Tỷ lệ sống}

Tỷ lệ sống của cá thí nghiệm cao, đạt trên $99 \%$ và không có sự sai khác đáng kể giữa các nghiệm thức. Kết quả nghiên cứu cũng cho thấy các loại thức ăn khác nhau không ảnh hưởng đến tỷ lệ sống của cá thí nghiệm.

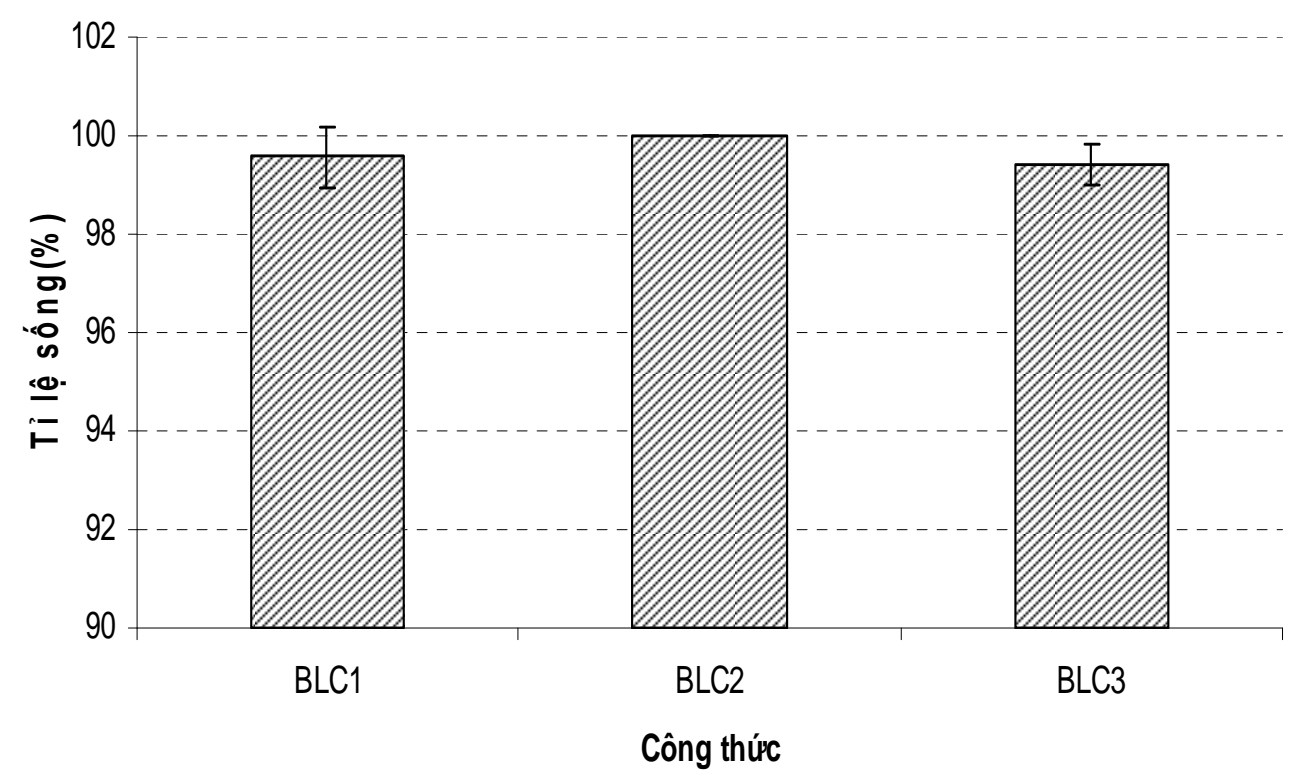

Hình 4: Tỷ lệ sống của cá trắm đen trong quá trình thí nghiệm 


\section{Hiệu quả sử dụng thức ăn và hệ số chuyển đổi thức ăn của cá trắm đen nuôi bằng các loại thức ăn khác nhau}

Thức ăn tiêu thụ theo trọng lượng khô (DFI) của nghiệm thức BLC2 là cao nhất $117,39 \mathrm{~g} / \mathrm{con} / 60$ ngày, sau đó đến nghiệm thức BLC1 (105.55 g/con/60 ngày) và thấp nhất là nghiệm thức BLC3 (97.16 g/con/60ngày) ( $\mathrm{P}>0,05)$.

Hiệu quả sử dụng thức ăn (FE) cũng có sự sai khác ở 3 nghiệm thức trong đó cao nhất là nghiệm thức $\mathrm{BLC} 2(0,58 \mathrm{~g} / \mathrm{g})$ sai khác có ý nghĩa $(\mathrm{P}<0,05)$ với hai nghiệm thức còn lại $\mathrm{BLC} 1(0,53 \mathrm{~g} / \mathrm{g})$ và $\mathrm{BLC} 3(0,46 \mathrm{~g} / \mathrm{g})$.

Hệ số chuyển đổi thức ăn (FCR): cá ăn thức ăn $\operatorname{BLC} 1(2,1) ; \operatorname{BLC} 2(1,9)$ và cả hai chỉ số đó đều thấp hơn hệ số chuyển đổi thức ăn khi ăn thức ăn $\operatorname{BLC} 3(2,4)(\mathrm{P}<0,05)$. So với nghiên cứu của Micheal C. Cremer, Zhou Enhua và Zhang Jian (2004) thì $\mathrm{FCR}=1,32$ và năm $2006(\mathrm{FCR}=1,08)$ ở cùng giai đoạn nuôi thì kết quả ở thí nghiệm này của chúng tôi là cao hơn.

Bảng 4: Hiệu quả sử dụng thức ăn và hệ số chuyển đổi thức ăn của cá trắm đen nuôi bằng các loại thức ăn khác nhau

\begin{tabular}{|c|c|c|c|}
\hline \multirow{2}{*}{ Chỉ tiêu } & \multicolumn{3}{|c|}{ Công thức thức ăn } \\
\cline { 2 - 4 } & BLC1 & BLC2 & BLC3 \\
\hline $\begin{array}{c}\text { Thức ăn tiêu thụ theo trọng lượng khô } \\
(\mathrm{DFI})(\mathrm{g} / \mathrm{con} / 60 \text { ngày) }\end{array}$ & $105.55 \pm 12.76^{\mathrm{a}}$ & $117.39 \pm 1.75^{\mathrm{a}}$ & $\begin{array}{c}97.16 \pm 4 . \\
47^{\mathrm{a}}\end{array}$ \\
\hline $\begin{array}{c}\text { Hiệu quả sử dụng thức ăn (FE) }(\mathrm{g} / \mathrm{g}) \\
\text { Hệ số chuyển đổi thức ăn }(\mathrm{FCR})\end{array}$ & $0.53 \pm 0.01^{\mathrm{a}}$ & $0.58 \pm 0.03^{\mathrm{b}}$ & $\begin{array}{c}0.46 \pm 0.0 \\
1^{\mathrm{a}}\end{array}$ \\
\hline
\end{tabular}

\section{Hiệu quả sử dụng protein}

Kết quả phân tích sinh hóa của cá trắm đen trước và sau thí nghiệm khi nuôi bằng các loại thức ăn khác nhau cho thấy cho thấy protein hầu như không có sự thay đổi của cá trước và sau thí nghiệm. Trước khi thí nghiệm thành phần protein của cá trắm đen là $16,8 \%$. Sau khi kết thúc thí nghiệm thành phần protein của cá trắm đen được nuôi bằng các loại thức ăn khác nhau lần lượt là BLC1 (16,76\%), BLC2 (16,12\%), BLC3 (16,95\%).

Sau 60 ngày nuôi hiệu quả sử dụng protein ở các công thức thức ăn khác nhau có sự sai khác rõ ràng trong đó cao nhất là công thức $\operatorname{BLC} 2(1,23 \mathrm{~g} / \mathrm{g}$ protein), tiếp đến là công thức $\mathrm{BLC} 1(1,18 \mathrm{~g} / \mathrm{g}$ protein) và thấp nhất là công thức $\mathrm{BLC} 3(0,96 \mathrm{~g} / \mathrm{g}$ protein). Và tất cả 
các nghiệm thức đều sai khác có ý nghĩa $(\mathrm{P}<0,05)$. Protein chuyển hóa cũng sai khác có ý nghĩa $(\mathrm{P}<0,05)$ ở giữa 3 công thức thức ăn là BLC1 $(19.59 \%)$; BLC2 $(19,90 \%)$; BLC3 $(16,89 \%)$. Như vậy, hiệu quả sử dụng và chuyển hóa protein của cá trắm đen ở trong thí nghiệm này là rất thấp.

Bảng 5: Hiệu quả sử dụng protein của cá trắm đen ở các công thức thí nghiệm

\begin{tabular}{|c|c|c|c|}
\hline \multirow{2}{*}{ Chỉ tiêu } & \multicolumn{3}{|c|}{ Công thức thức ăn } \\
\cline { 2 - 4 } & BLC1 & BLC2 & BLC3 \\
\hline Protein của cá trước thí nghiệm $(\%)$ & 16.8 & 16.8 & 16.8 \\
\hline Protein của cá sau thí nghiệm $(\%)$ & 16.76 & 16.12 & 16.95 \\
\hline Hiệu quả sử dụng protein (PER) (g/g protein) & $1.18 \pm 0.06^{\mathrm{b}}$ & $1.23 \pm 0.001^{\mathrm{c}}$ & $0.96 \pm 0.0^{\mathrm{a}}$ \\
\hline Protein chuyển hóa $(\%)$ & $19.59 \pm 0.15^{\mathrm{b}}$ & $19.90 \pm 0.14^{\mathrm{c}}$ & $16.89 \pm 0.85^{\mathrm{a}}$ \\
\hline
\end{tabular}

\section{Chi phí thức ăn}

Bảng 6: Chi phí thức ăn để thu được $1 \mathrm{~kg}$ cá tăng trọng

\begin{tabular}{|c|c|c|c|}
\hline Thức ăn thí nghiệm & Giá thức ăn (đ/kg) & HSTA & Chi phí thức ăn(đ/kg) \\
\hline BLC1 & 21700 & 2,1 & 45570 \\
\hline BLC2 & 21000 & 1,9 & 39900 \\
\hline BLC3 & 20600 & 2,4 & 49440 \\
\hline
\end{tabular}

Để thu được $1 \mathrm{~kg}$ cá tăng trọng dùng thức ăn BLC3 chi phí về thức ăn lớn nhất (49440 đồng), tiếp đến là thức ăn BLC1 (45570 đồng) và thấp nhất là thức ăn BLC2 (39000 đồng). Do thức ăn BLC2 có thay thế $25 \%$ bột cá bằng men bia nên giá nguyên liệu cho $1 \mathrm{~kg}$ thức ăn giảm hơn so với thức ăn BLC1 (100\% bột cá). Trong khi đó thức ăn BLC3 có thay thế $50 \%$ bột cá bằng men bia nên giá thành nguyên liệu cho $1 \mathrm{~kg}$ thức ăn là thấp nhất, tuy nhiên khi nuôi cá trắm đen bằng thức ăn này thì cho tốc độ tăng trưởng chậm và hệ số thức ăn cao vì thế chi phí thức ăn cho $1 \mathrm{~kg}$ cá tăng trọng ở thức ăn này là lớn nhất.

\section{Thảo luận}

Cá trắm đen là loài cá ăn thịt, ở thời kì đầu khi chế biến thức ăn thường hay dùng bột cá với một lượng rất lớn, nhưng gần đây do nguồn cung cấp ngày càng hạn chế không 
cung cấp đủ bột cá, giá cả lại ngày một cao, việc thay thế bột cá bằng các nguồn đạm rẻ tiền, sẵn có có ý nghĩa quan trọng.

Michael C. Cremer, Zhang Jian and Zhou (2004) nghiên cứu sử dụng đậu tương ương cá trắm đen giống đạt trung bình tăng trưởng $0,37 \mathrm{~g} / \mathrm{con} / \mathrm{ngày.} \mathrm{Tỷ} \mathrm{lệ} \mathrm{sống} \mathrm{đối} \mathrm{với} \mathrm{cá}$ trắm đen giống là $94,3 \%, \mathrm{FCR}=0,95$. Thí nghiệm thay thế một phần bột cá bằng bột đậu tương hoặc bột đậu Lupin sử dụng trong ương giống cá trắm đen, trên cơ sở đảm bảo hàm lượng protein là $40 \%$. Thí nghiệm đã kết luận rằng bột đậu tương và bột đậu Lupin hoàn toàn có thể thay thế được bột cá, khi các kết quả về tăng trọng, hệ số thức ăn, tỷ lệ protein hiệu quả và giá trị protein tạo ra giữa các công thức khác nhau không đáng kể (Lee Dan và ctv, 2006). Ngoài ra có thể thay thế bột cá bằng các loại protein động vật có giá thành thấp như bột máu, nhộng tằm (lượng bột máu và nhộng tằm khoảng 2 - 4\% là thích hợp); Các loại khô dầu thực vật (khô dầu đậu nành đậu, khô dầu hạt cải, hạt bong,...) chiếm khoảng 50\%-70\% (Leng Xiang-Jun và Wang Zun, 2003).

Theo Lee Dan và nnk (2006 ) cho biết ngoài thành phần dinh dưỡng trong thức ăn phải đáp ứng đủ nhu cầu dinh dưỡng cho cá sinh trưởng thì còn phải chú ý đến thành phần nguyên liệu dinh dưỡng hợp lý trong thức ăn vì mỗi loại khác nhau sẽ có khả năng tiêu hóa khác nhau. Trong thí nghiệm của chúng tôi nhận thấy thức ăn BLC2 cho tốc độ tăng trưởng nhanh nhất, hiệu quả sử dụng protein cao hơn các nghiệm thức khác. Hệ số chuyển đổi thức ăn của cá ăn thức ăn BLC2 thấp hơn so với thức ăn sử dụng $40 \%$ bột cá. Như vậy có thể thay thế $25 \%$ bột cá bằng men bia khô cho kết quả tăng trưởng nhanh hơn so với sử dụng $100 \%$ bột cá. Tuy nhiên, thay thế $50 \%$ bột cá bằng men bia làm giảm tốc độ tăng trưởng, tăng hệ số thức ăn và giảm hiệu quả sử dụng protein (BLC3). Thí nghiệm này cũng trùng hợp với báo cáo của Lee Dan và nnk (2006) đã đưa ra là khả năng tiêu hóa của các loại men bia làm thức ăn cho cá trắm đen là $82,1 \%$ và khả năng tiêu hóa của bột cá là $64,5 \%$. Tuy nhiên, thí nghiệm này cũng chưa nghiên cứu được sự ảnh hưởng của men bia trong công thức thức ăn thay thế bột cá đối với khả năng tiêu hóa, tích lũy lipid và tích lũy năng lượng của cá trắm đen. Với những kết quả của thí nghiệm này có thể kết luận công thức thức ăn BLC2 (thay thế $25 \%$ bột cá bằng men bia) là tốt nhất. Tuy nhiên vẫn phải tiếp tục cải tiến nhằm giảm hơn nữa hệ số thức ăn.

\section{KẾT LUẬN}

- Cá trắm đen nuôi bằng thức ăn BLC2 (thay thế $25 \%$ bột cá bằng men bia) có tốc độ tăng trưởng, tỷ lệ sống, hệ số chuyển đổi thức ăn cao hơn so với thức ăn BLC1 (100\% bột cá) và $\mathrm{BLC} 3$ (thay thế $50 \%$ bột cá bằng men bia). 
- Hiệu quả sử dụng và chuyển hóa protein của cá trắm đen ở trong thí nghiệm này là rất thấp.

\section{TÀI LIỆU THAM KHẢO}

1. Nguyễn Văn Hảo, Ngô Sỹ Vân, 2001. Cá nước ngọt Việt Nam. Tập 1, Họ cá chép (Cyprinidae). NXB Nông nghiệp, Hà Nội (622 trang).

1. Nguyễn Thị Diệu Phương và ctv, 2009. Hiện trạng nuôi cá trắm đen thương phẩm ở vùng đồng bằng sông Hồng. Báo Nông nghiệp Việt Nam, số 2/2009.

2. Ben-Ami F.; Heller J, 2001. Biological Control of Aquatic Pest Snails by the Black Carp Mylopharyngodon piceus. Academic Press. Biological Control, Volume 22, No 2, 131-138 (8).

3. Bíró (1999). Mylopharyngodon piceus (Richardson, 1846). In "The freshwater fishes of Europo", Volume 5/I, Cyprinidae 2/I, pp. 347-365. P. Banarescu (Editor). AULU - Verleg, Wiebelshiem, Germany.

4. Michael C. Cremer, Zhang Jian and Zhou, 2004. Black Carp Fingerling Production with Soy-Maximized Feeds. Results of ASA/China 2004 Feeding Trial 35-04-82. American Soybean Association, P.R. China.

5. Michael C. Cremer, Zhou Enhua and Zhang Jian, 2006. Feeding Trials Demonstrate Effectiveness of Soy-Based, High Protein Feed for Black Carp Production. ASA-IM/China Aquaculture Program. Black carp, soybean meal, 80:20 pond technology, China.

8. Lee Dan et al, 2006. Black carp nutient research. Journal of Shanghai Fisheries University, No. 2/2006.

9. Leo Nico and Pam Fuller, 2007. Mylopharyngodon piceus. USGS Nonindigenous Aquatic Species Database, Gainesville, FL.

10. Leng XiangJun, Wang DaoZun, 2003. Nutrient requirements and feed manufacturing technology of Mylopharyngodon piceus Richardson. Journal of Shanghai Fisheries University, Vol. 12, No. 3, 265-270.

11. Leo G.Nico, James D.William and Howard L. Jelks, 2005. Black Carp: Biological Synopsis and Risk Assessment of an Introduced Fish. American Fisheries Society Special Publication 32, Bethesda, MD. 
12. Nico et al, 2005. Black carp: biological synopsis and risk assessment of an introduced fish. American Fisheries Society Special Publication, 32. 337 pp.

\title{
EFFECT OF DIFFERENT FEED ON GROWTH PERFORMANCE, SURVIVAL RATE AND PROTEIN DEPOSITED OF BLACK CARP MYLOPHARYNGODON PICEUS (RICHARDSON, 1846)
}

\author{
TA THI BINH, NGUYEN VAN TIEN
}

\begin{abstract}
Summary: This study was undertaken to determine suitable feed for black carp (Melopharyngodon piceus) 30 -100g stage. Three different feed formulations were used BLCl, BLC2, BLC3. Experimental fish werw stocked in 6 hapa in 03 ponds with $350 \mathrm{~m}^{2} / \mathrm{hapa}$, density stocking 1 fish $/ \mathrm{m}^{2}$. Feeding twice/day with above feed kinds at demand of fish. Growth rate of fish was check every 20 days, each to weigh 50fish/hapa. Survival of fish, FCR and percent protein deposited were determine at the end of the experiment. The results show that, after 60 days Black carp reach fastest growth at BLC2 (ADG $0.11 \mathrm{~cm} /$ fish/day and 1.14 g/fish/day; SGR 0.69\%/ngày and 2.17\%/day), follow is BLCl (ADG $0.1 \mathrm{~cm} /$ fish/day and 0.92 g/fish/day; SGR 0.59\%/day and 1.85\%/day) and slowest at BLC3 (ADG $0.085 \mathrm{~cm} /$ fish/day and $0.74 \mathrm{~g} /$ fish/day; SGR 0.58\%/day and 1.72\%/day). Average weight of fish at the end of the experiment is $93.61 \mathrm{~g} /$ fish, $86.96 \mathrm{~g} /$ fish and $68.9 \mathrm{~g} /$ fish at BLC2, $\mathrm{BLC1}$ and $\mathrm{BLC} 3$ respectively. The survival of experimental fish at 3 feed formulations equivalent and over 99\%, FCR of BLC1 (2,1), BLC2 (1.9) and BLC3 (2.4). Percent protein deposited of BLC1 (19.59), BLC2 (19.90) and BLC3 (16.89). ANOVA analysis shows that the differences between the feed formulations about $A D G$ weight, $F C R$ are statistical significance $(P<0.05), S G R(L, W), A D G$ $(L)$ and PPD, survival are not significantly diferent $(P>0.05)$.
\end{abstract}

Keywords: Black carp, growth, protein deposited

Ngày nhận bài: 15 - 11 - 2009

Ngườ nhận xét: PGS. TS. Nguyễn Chu Hồi 